Article

\title{
Consumer Willingness To Pay for Proenvironmental Attributes of Biogas Digestate-Based Potting Soil
}

\author{
Carsten Herbes ${ }^{1, * \mathbb{C}}$, Johannes Dahlin ${ }^{1}$ and Peter Kurz ${ }^{2}$ \\ 1 Institute for International Research on Sustainable Management and Renewable Energy (ISR), \\ Nuertingen-Geislingen University, Neckarsteige 6-10, 72622 Nuertingen, Germany; \\ johannesdahlin@googlemail.com \\ 2 BMS Marketing Research + Strategy GmbH, Landsberger Str. 487, 81241 Munich, Germany; \\ p.kurz@bms-net.de \\ * Correspondence: carsten.herbes@hfwu.de
}

Received: 11 July 2020; Accepted: 6 August 2020; Published: 9 August 2020

\begin{abstract}
Biogas from anaerobic digestion has become an important element in the renewable energy portfolio of many countries. In anaerobic digestion, digestate is produced as a byproduct. This could be used to produce fertilizers and potting soils for home gardeners substituting mineral fertilizers or peat-based products. However, this depends on consumer willingness to pay (WTP) for such products, which we investigate in this study. To this end, we conducted a discrete choice experiment (DCE) with 507 private consumers. From the 6084 decisions made, we derived Bayesian part-worth utilities using a preference share model and so calculated the WTP for different proenvironmental attributes of potting-soil products. We also assessed the influence of proenvironmental attitudes on the WTP. We discovered five distinct consumer groups in our respondents. Some show a significant WTP for proenvironmental attributes such as "organic", "peat free", and "without guano". Three descriptions of digestate as a "renewable resource", a "fermentation residue", or a "biogas residue" elicited three markedly different WTP responses across all classes, with "renewable resource" garnering the highest WTP and "biogas residue" the lowest. Consumers with a stronger proenvironmental attitude exhibited a higher WTP for proenvironmental attributes. Our results can help marketers of digestate-based potting soils discover suitable price points for their products and design differentiated pricing strategies across consumer groups.
\end{abstract}

Keywords: biogas; biogas digestate; biogas residues; marketing; price; discrete choice experiment; willingness to pay; consumer; potting soil; fertilizer

\section{Introduction}

Many countries have recognized the potential of anaerobic digestion (AD). Throughout Europe, the rapid emergence of biogas plants deploying AD technology can be seen [1]. The European Biogas Association [2] estimates that 17,662 plants were in operation in Europe at the end of 2016. [3] reports that, globally, the electrical generation capacity of biogas plants stood at $17 \mathrm{GW}$ at the end of 2017, of which roughly $12 \mathrm{GW}$ came from plants in Europe, where the three biggest markets have been Germany, Italy, and the UK.

As promising as biogas technology is, AD plants face waste-management challenges, namely, how to manage the large volume of digestate produced as a byproduct of plant operations. The volume of digestate often approximates that of the input material [4]. Biogas digestate and the nutrient it contains have been reported to be a problem in many countries in Europe and also in China $[5,6]$ and acceptance by farmers is often low [7]. 
The nutrient content of this digestate flow is too great to ignore. For a biogas plant based on energy crops, contents range from 1.2 to $9.10 \mathrm{~kg}$ of nitrogen per tonne of fresh matter, 0.4 to $2.6 \mathrm{~kg}$ of phosphorous, and 1.2 to $11.5 \mathrm{~kg}$ of potassium [8]. Nitrogen and phosphorous levels in digestates from plants operating on food waste tend to be double those from plants operating on energy crop-based plants [9]. The estimated phosphorous content of all German biogas plants exceeds $80 \%$ of the phosphorous in all commercial fertilizer sold in Germany [10].

The capacity of the agricultural sector to absorb the digestate flow has been limited for several reasons. First, the nitrogen content in digestates varies and is usually not fully available to plants in the year of application $[8,11]$, so digestate-based fertilizers are not a one-to-one replacement for chemical fertilizers whose nutrients are immediately available in amounts that can be calculated precisely. Second, inert materials, such as plastics, may be present in the digestate product, discouraging its use on a farm [12]. Third, biogas plants are increasingly being held accountable for high levels of nitrogen in the groundwater [13], a view that has evolved over the last decade and reflects the heated controversy that these plants have generated in the discourse on agricultural policy and practices $[14,15]$.

So, we conclude that realizing the promise of biogas depends on developing channels for digestate to be used productively as a substitute, e.g., for mineral fertilizer or peat-based soil products, rather than forming another kind of waste. One perhaps easily overlooked, yet quite promising, channel is potting soil for home gardeners, a market that not only produces troublesome amounts of mineral-based fertilizers and soil additives, but one that also puts pressure on the global ecosystem through the harvesting of peat, a common soil additive. Globally, peat lands contain concentrated accumulations of carbon from decaying vegetation [16]. The draining of these peat lands to enable harvesting the peat for use in gardening and other applications releases massive amounts of $\mathrm{CO} 2$ into the atmosphere [17]. This has made replacing peat a priority for both academia and market actors [18].

Digestate from AD plants has qualities that make it attractive both as a substitution product for peat and as a slow-release organic nutrient source. Should digestate-based products succeed in the home gardening market, it would not only provide a means to recover the nutrient contents in the digestate but would also help relieve pressure on peat lands and lessen the demand for mineral-based fertilizers.

A few biogas plants have started to market their digestate to home gardeners (Figure 1). All digestates require substantial processing or recycling to become marketable, especially to increase the nutrient content per unit volume [12,19-21].

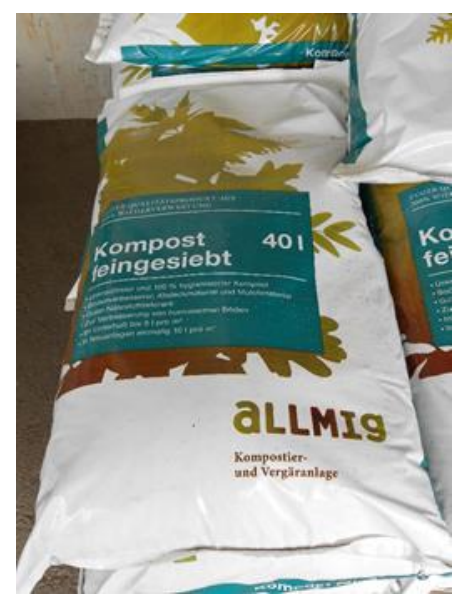

Figure 1. Example of a composted digestate product offered at an anaerobic digestion (AD) site; source: J. Dahlin.

For the digestate-into-potting soil path to be viable for plant operators, willingness to pay (WTP) must be large enough to at least cover the operator's processing and distribution costs. No rational operator would make a significant investment without some expectation of return, which makes it necessary to have reliable estimates of consumer WTP for digestate-based potting soils and their 
diverse proenvironmental attributes. Past research has established some facts that we can build on; a recent study by [22] revealed the importance to certain consumer segments of proenvironmental attributes such as "peat free", "organic", and "without guano", which is different from how farmers judge biobased fertilizers $[23,24]$ but left open the question of WTP, which forms the research gap on which we build our paper. We use a choice-based approach, since it allows discerning the effects of different attributes and their levels on WTP and thus offers detailed insights, which are valuable both for developing theory as well as for taking decisions on product design and pricing.

This paper forms part of an ongoing discourse on biogas digestate [12,20,25]. It aims at contributing to the body of research in the following ways: for the first time, we estimate WTP of private gardeners for digestate-based potting soils. Moreover, we show differentiated WTPs for different customer groups, sales channels and product attributes. The results can also inform research on the marketing of other digestate-based products, such as fertilizer and compost. Potting soil marketers can take away insights for setting price points that strike a balance between recovering costs and encouraging demand for environmentally friendly gardening products and researchers working on other digestate-based products can use our results as a point of departure for their enquiries. In a wider perspective, the results may even inform research on other proenvironmental waste-based products. The paper proceeds as follows: in Section 2, we introduce our materials and methods, including the building of our hypotheses. In Section 3, we present our results, which are discussed and followed by a conclusion in Section 4.

\section{Materials and Methods}

We elected to explore the willingness to pay (WTP) of home gardeners for digestate-based potting soils and their diverse proenvironmental attributes by means of a discrete choice experiment (DCE) implemented through an online questionnaire. We estimated part-worth utilities based on the DCE, with a latent class and a hierarchical Bayes model, to identify marketable consumer segments and calculate corresponding WTP levels.

\subsection{Discrete Choice Experiments (DCE) in Consumer Research}

Since the seminal work of [26] in integrating conjoint and discrete choice approaches, DCE has evolved into one of the most widely used methods in market research. Initially, discrete choice models (DCM) could only be evaluated at the aggregate respondent level but, in the mid-1990s, hierarchical Bayes (HB) estimation procedures emerged to estimate part-worth utilities at the pseudoindividual level [27-29]. Little data from each respondent is needed, and it is even possible from the mathematics to estimate pseudoindividual part worths when there are more parameters than observations.

With the ability to estimate pseudoindividual utility values, DCEs have gained widespread popularity throughout the social sciences. Since the Bayesian breakthrough, DCEs have not only been used in traditional fields of marketing, like food products [30-32], but also in valuations of nonmarketable environmental goods and services [33-36].

In developing a DCE, experimental designers decompose specific goods or services into product features (attributes), e.g., cost and color, with corresponding attribute levels, e.g., $1 €, 2 €$, or $3 €$ for cost and yellow, orange, and red for color. The overall utility of the product is the combination of all attributes and level values-all part-worth utilities—belonging to the product [37]. To investigate the impact of different attributes and their corresponding part-worth utilities, combinations of attributes are independently but systematically varied during an interview. Several selections of products are presented to the respondent in what are known as choice tasks. Each choice task simulates the tradeoff decisions involved in a real-world purchase where the customer has to choose from competing products on the shelf.

Each respondent completes a series of choice tasks during an interview. Which products and choice tasks are shown to a single respondent depends on the experimental design. The design guarantees that all attributes and levels are shown in an equal distribution over all respondents, ensuring no bias 
exists between the attributes and levels. The sequence of choice tasks over all respondents results in a collection of tradeoffs that allows the social scientist to gain insight into consumer preferences [38].

The utility derived from a DCE is modeled by what has become a well-tested standard random utility model (RUT) [39-41] for choice applications. The model describes how individuals make choices and assumes that a person always selects the product with the highest benefit.

The basic formula for the RUT (Formula (1)) is [38,42,43]:

$$
\mathrm{Uin}=\mathrm{Vin}+\varepsilon \text { in }
$$

where the unobservable (latent) utility Uin that an individual $i$ associates with an alternative $\mathrm{n}$ is expressed as the sum of an explainable utility component, Vin, and a random and unexplainable component $\varepsilon$ in [41]. The error term is often interpreted as representing unmeasured characteristics that influence the explainable utility.

\subsection{Using DCE to Estimate WTP}

To set prices that yield profits, producers need to be able to estimate the price sensitivity of consumers. For this, they use price-response functions [44] based on consumer willingness to pay (WTP). Here, WTP is defined as the maximum price a consumer is willing to pay for a product feature [45]. Although marketing literature proposes a broad range of methods to measure WTP at the individual consumer level [46], DCEs have assumed a prominent role in both marketing practice [47,48] and academic research [26].

The reason may be that a DCE allows the integration of a "no choice" option. By using the utility value of the "no choice" option as a reference point, absolute WTP values can be estimated, a considerable improvement over prior methods yielding only relative WTP differences between alternative attribute levels.

To illustrate, our model defines WTP as the monetary amount required to compensate a consumer for the loss of a product value. WTP for a product feature is the amount of money that must be given to the consumer so the consumer is indifferent to purchasing the product with the feature or purchasing the "no choice" product without that feature but receiving the monetary discount. That is, the willingness to pay for an attribute level is calculated as the price discount that makes not having the product feature of equal utility to the consumer as having it [49].

This has proven to be a useful approach to overcoming what past research has revealed, namely, that consumers systematically tend to overstate their willingness to buy [26,50,51]. This means attempts to derive WTP directly can be expected to produce overestimations. However, broad consensus exists that approaching the question indirectly via a compensating discount leads to more accurate WTP estimates [52]. Therefore, DCM is one of the preferred techniques to estimate WTP. DCM use a compensatory choice rule and could calculate the WTP in relation to the "no choice" option; these properties avoid the overestimation of the WTP. It must be kept in mind, however, that WTP only captures the demand side of a market; it cannot measure the profitability of a product as it does not address the costs to supply. WTP is what a consumer would pay, but it is independent of costs or competitive structure in a sector.

\subsection{Experimental Design}

An exploratory and qualitative phase is crucial for designing a valid and applicable DCE [53]. Ours was conducted through 20 qualitative interviews with home gardeners; these were recorded and transcribed. This data was analyzed using the content analysis software MAXQDA, which helped us extract the attributes most relevant to the gardeners. Based on our findings, we designed the subsequent survey and DCE. All questions within the online survey as well as the attributes thus trace back to the qualitative interviews [25]. 
Table 1 displays the attributes for the potting soil DCE that we developed, along with their level values. These combinations were derived through comparison to the ones found on product packaging in German home garden stores. To the actual attribute levels found on these packages, we added a hypothetical resource attribute to investigate consumer perception of different raw materials. All three level values in Table 1-"from renewable resources", "from fermentation residues", and "from biogas residues" — describe the same digestate-based raw material, but each differs in the naming used.

Table 1. Potting soil attributes and their level values.

\begin{tabular}{|c|c|}
\hline Attribute & Attribute Levels \\
\hline Potting soil type & $\begin{array}{ll}\text { - } & \text { Universal (general-purpose) potting soil } \\
\text { - } & \text { Flower (specific purpose) potting soil }\end{array}$ \\
\hline Brand name & $\begin{array}{ll}\text { - } & \text { Premium brands (e.g., Compo, Neudorff) } \\
\text { - } & \text { Middle class brands (e.g., Gartenkrone, Flora Self) } \\
\text { - } & \text { Private labels of garden stores (e.g., Obi, Toom) }\end{array}$ \\
\hline Label I & $\begin{array}{l}\text { - Labeled as "organic" } \\
\text { - Not labeled }\end{array}$ \\
\hline Label II & $\begin{array}{l}\text { - Labeled as "peat free" } \\
\text { - Not labeled }\end{array}$ \\
\hline Label III & $\begin{array}{ll}\text { - } & \text { Labeled as "containing guano" (seabird manure) } \\
\text { - } & \text { Not labeled } \\
\text { - } & \text { From renewable resources }\end{array}$ \\
\hline Resource (raw materials used) & $\begin{array}{l}\text { - } \quad \text { From fermentation residues } \\
\text { - } \quad \text { From biogas residues } \\
\text { - } \quad 4 €\end{array}$ \\
\hline Price (40-liter package) & $\begin{array}{ll}\text { - } & 6 € \\
\text { - } & 8 €\end{array}$ \\
\hline
\end{tabular}

\subsection{Data Collection and Analysis}

Data were collected in collaboration with the market research institute KANTAR TNS. KANTAR's national representative online panel has access to 160,000 members in Germany. At the beginning of the interview, a screener section was asked to select private gardeners that had to be at least 18 years old and have purchased potting soil within the last three years. We expected to receive good response rates at the beginning of the gardening season when home gardeners increase their efforts to reactivate and maintain their garden after the winter season.

To conduct fieldwork, we used Sawtooth Software SSI/WEB package for the main questionnaire and the DCE part. The experimental design was computed with the complete enumeration algorithm that is part of this software package. The design generation resulted in 100 versions with 12 choice tasks each. One version with 12 screens (choice task) was answered by each respondent. Each design version was shown at least five times. The experimental design was tested with 500 synthetic respondents to guarantee that the effects and random errors of all attributes and levels were as small as possible $(<0.01)$ and that one- and two-way level balance was obtained by all design versions $(+/-2)$. Each choice task presented three different potting-soil products and the no-choice option.

After fieldwork, a quality control took place and respondents with fast, systematic, or fatigue answering behavior and with inconsistent answers were removed from further analysis. After the quality control, 507 respondents remained for further analysis. Each of the 507 respondents have evaluated 36 potting-soil products and chose 12 of them or the no-choice option to express their preferences, yielding a total of 6084 choices for estimating the part-worth utilities.

Several methods exist for analyzing choice data sets and calculating utility values. The latest and most refined method, used in this study, is based on the hierarchical Bayes regression approach to estimating pseudoindividual part-worth utilities [54,55]. Hierarchical means that the model operates on two levels, where the upper level assumes that the part-worth utilities are represented by a multivariate 
normal distribution. At the lower level, however, the possibility of choosing one option over another is accompanied by a multinomial logit model for each respondent.

The second analytic approach used in this study was latent class analysis (LCA), which was conducted to identify subgroups of respondents based on shared preferences for potting-soil products. These subgroups, or latent classes, share distinct and sometimes contrasting preferences for specific product attributes. These preferences can help digestate marketers design product offerings segmented into specific sales channels. Latent class uses an E-M algorithm and therefore no underlying distribution assumption of the data is required. The results not only provide useful market segments but they could be used as proof for the assumption that the data is distributed multivariate normal, which is necessary to meet the demands of the hierarchical Bayes approach. The latent class results confirm both a useful segmentation solution and the higher heterogeneity in the data that follows in some way multivariate normal distribution.

The provided goodness-of-fit measures from both estimation techniques show reasonable fit. RLH (0.713) and pseudo $\mathrm{r}^{2}(0.694)$ are much higher than the chance rate (0.25) and the RMS measures show larger values (2.319) compared to the "null model" (0.804), which indicates that the estimated model provides a very good approximation of the underlying data structure.

\subsection{Selection of Accompanying Variables}

We derived a set of accompanying variables to capture characteristics of our respondents that helped us analyze the data. These are listed in Table 2. In addition to these variables, we used the green consumer values [56] to characterize our respondents' attitudes towards the protection of the environment.

Table 2. Accompanying variables.

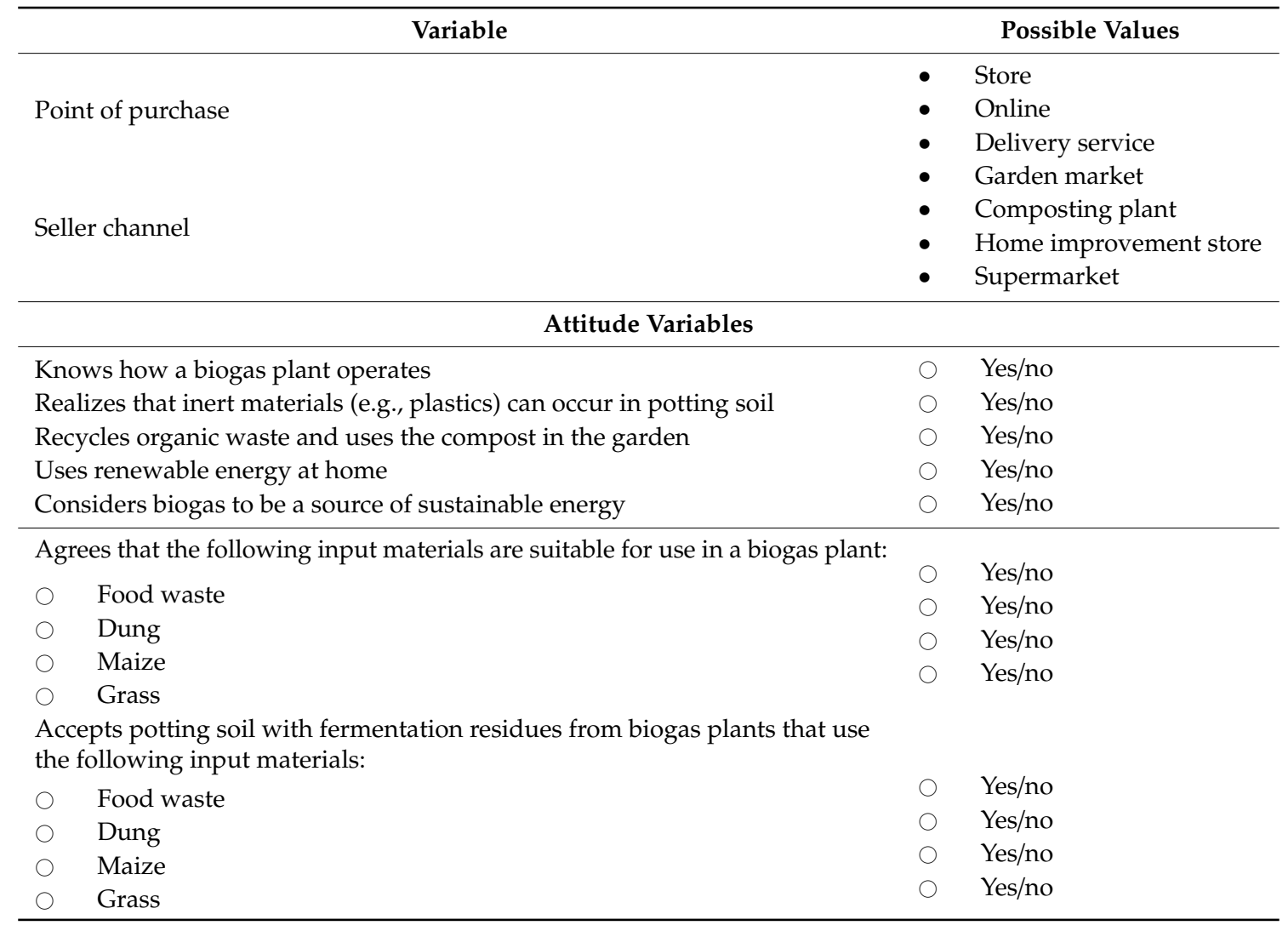




\subsection{Theory and Hypotheses Development}

We started from past research that has demonstrated positive part-worth utilities for various proenvironmental attributes of compost and potting-soil products [22]. This approach builds on the broader research into consumer WTP for proenvironmental products and services. The following products and services, among others, have been frequently analyzed using WTP studies: organic food (with research showing a willingness to pay a premium of about $30 \%$ over conventionally grown food) [57], electric vehicles [58], packaging [59], apparel [60], and electricity [61]. The underlying theories posit that a product is a bundle of attributes that generate different utilities for the consumer [37] and that consumers try to maximize their utility [41]. Moreover, due to the compensatory nature of the model, it posits that utilities from choice models could be expressed as the WTP between specific attributes of interest. If a financial variable is in the tradeoff (price), the WTP can be expressed in dollar terms [62]. The WTP measure represents the amount by which a price could be raised and leave the utility for the product the same when including a feature [63]. The utility maximization of the respondent and the comparative nature of the model makes it possible to compare every feature in dollar terms.

To identify proenvironmental attributes of compost and potting soils, we first compiled attributes from previous qualitative interviews with private gardeners about potting soil preferences [25]. We focused on attributes that also pertain to biogas digestate and can be used in communication when selling digestate-based potting soils. Two are especially relevant to the environmentally minded consumer: first, biogas digestate is an organic product that can replace peat in potting soil [22]; second, digestate provides phosphorous that would otherwise often be taken from guano.

We focused on these attributes because consumers have increasingly become aware of the environmental cost of draining peat land [64], though public perception is divided [65]. So too is the perception of guano, with some consumers favoring it in their potting soil and fertilizer products and others intent on avoiding it $[22,64]$.

From these considerations, we derived our first set of hypotheses:

Hypothesis 1. Proenvironmental attributes of potting soils increase consumer WTP.

Hypothesis 1.1. The attribute "organic" increases consumer WTP.

Hypothesis 1.2. The attribute "peat free" increases consumer WTP.

Hypothesis 1.3. The attribute "with guano" decreases consumer WTP.

Consumer research has also established the influence, though sometimes indirect, on green preferences and WTP exercised by general values [66-71] and by specific attitudes pertaining to environmental protection [72-74]. Thus, our second hypothesis became:

Hypothesis 2. Hypothesis 2. The positive effects of the attributes from Hypothesis1 are influenced by attitudes about the environment. Consumers with strong proenvironmental attitudes show a higher WTP for proenvironmental attributes than do consumers with weak proenvironmental attitudes.

We next considered public perception of digestate, starting with research on the social acceptance of biogas. This specific renewable technology has met with reservations by consumers in many countries, most notably Germany, where biogas is associated with energy crops, especially maize. The public discourse has created the disparaging neologism "maizification" (of the landscape), and public debate often culminates in the "fuel versus food argument" [75-77]. Even biobased packaging from biomethane has met with strong consumer reservations in Germany and also in the United States and France [78]. However, in other countries, the discourse in the media has been favorable to biogas 
and its potential for the future, e.g., in Finland [79]. In the balance, however, we formulated our third hypothesis:

Hypothesis 3. The attribute "from biogas residues" decreases consumer WTP.

Finally, we wanted to support marketers who seek a differentiated pricing strategy across sales channels. Past research has shown that private gardeners primarily buy potting-soil products in stores as opposed to online. Among the stores, DIY stores and garden centers are most popular [22]. Studies from the general retail pricing literature suggest price discrimination across channels [80], which is based on differences in consumers' WTP between channels [81]. This led to our fourth set of hypotheses:

Hypothesis 4.1. Consumers who primarily purchase potting soil in the nursery or garden center show a higher WTP for proenvironmental attributes than consumers who primarily buy potting soil in the supermarket.

Hypothesis 4.2. Offline buyers (direct and delivery) show a higher WTP for proenvironmental attributes than online buyers.

We examine these hypotheses against our results in Section 3.

\section{Results}

In this section, we assess the impact the attributes listed in Table 1 had on consumer WTP for the potting-soil products modeled in our DCE. In presenting the results from our choice model, we follow a ceteris paribus approach and consider only one attribute at a time. We recognize that companies selling potting soil and compost offer products that combine a bundle of attributes and, for this reason, we caution against misinterpreting single-attribute WTPs. It would be an error to think the total WTP for a product could be derived by adding up all the WTP values for the corresponding single attributes. In most cases, the WTP for the bundle of attributes will be lower than the sum of the WTPs for the single attributes.

To illustrate how to interpret our WTP results, consider Figure 2, showing two products that are polar opposites under our choice model. Product 1 is a general-purpose (i.e., universal) potting soil from a private label brand. It lacks the attributes "organic" and "peat free" and contains guano. It is identified as "from biogas residues". This product elicits a WTP of 4.54 euro per 40-liter pack in our results. Product 2 is a special-purpose potting soil designed to support flowering. It carries a premium brand and is marked with both proenvironmental attributes. Furthermore, it is free of any guano and is described as "from renewable resources". This product elicits an overall WTP of 7.81 euro. The WTP difference amounts to 3.27 , which means a provider could ask for a price premium of $72 \%$ for the second product. This illustrates how to interpret our WTP results to identify pricing opportunities offered by suitable product designs. 


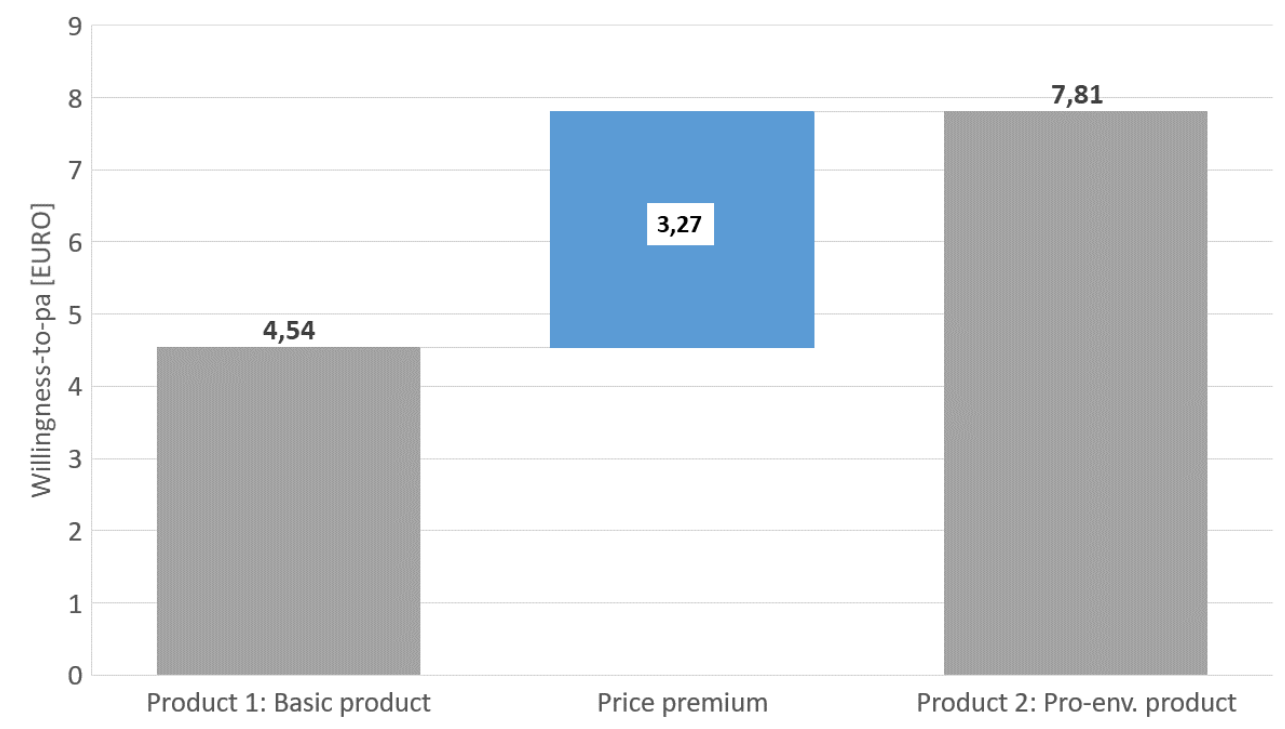

Figure 2. Willingness to pay (WTP) for two exemplary products.

\subsection{Willingness to Pay for Proenvironmental Attributes by Latent Class}

In Table 3, we present the average WTP associated with each of the potting soil attributes tested. Results are presented for all respondents $(n=507)$ and for each of the respondent subgroups identified through latent class analysis. Note that our choice model constrained price differences to a maximum of 4.00 euro. Therefore, in the following, a WTP of 4.00 euro should be understood to mean at least 4.00 euro.

When considering all respondents, Table 3 shows a positive WTP for both "organic" and "peat-free" options, though the size of the WTP varies greatly by latent class. Group 1 ("premium brand customers"), group 3 ("label-oriented middle-class customers"), and group 5 ("multicriteria customers") were willing to pay from 2.15 to 4.00 (max value) euros for "organic" potting soil (Hypothesis 1.1) while groups 2 and 4 ("price-sensitive customers") exhibited a WTP of only 0.70 and 0.11 euro, respectively.

Results were similar for the "peat-free" attribute (Hypothesis 1.2), although group 4 actually assigned a negative WTP to this. Other groups assigned a slightly lower WTP than for "organic" but, overall, the proenvironmental attributes elicited a positive WTP (Hypothesis 1).

Results for the attribute "with guano" (Hypothesis 1.3) were mixed and illustrate the importance of considering consumer subgroups. Across all respondents, the WTP for "with guano" was positive, seeming to contradict Hypothesis 1.3 and suggesting consumers would not be willing to pay to replace guano in their potting soil with a more environmentally friendly source of phosphorous. However, looking at the latent classes shows that only group 5 ("guano seeking") assigns a positive WTP (the maximum possible) to guano, while the other four groups all assign negative WTPs.

Negative WTPs are interpreted to mean these subgroups would prefer a potting-soil product that did not contain guano. Groups 1 and 3, in fact, were on average willing to pay four euro more for potting soil that did not contain guano. That is, customers in these two groups were willing to pay as much not to have guano in their potting soil as customers in group 5 were willing to pay to have it. That result alone highlights the importance of segmented approaches to the marketing of potting soil.

Overall, Hypothesis 1.3 is confirmed for all but one of the five subgroups.

\subsection{Willingness to Pay and Strength of Proenvironmental Attitudes}

Table 4 presents the average WTPs associated with each of the potting soil attributes, here presented in association with the strength of the consumer's proenvironmental attitude. Our Hypothesis 2 (namely, "consumers with strong proenvironmental attitudes show a higher WTP for proenvironmental attributes than consumers with weak proenvironmental attitudes") is supported by these results. 
Table 3. Average WTP for attributes by latent classes *

\begin{tabular}{|c|c|c|c|c|c|c|c|c|c|c|c|c|c|}
\hline \multirow[b]{4}{*}{ Attribute } & \multirow[b]{4}{*}{ Level } & \multirow{2}{*}{\multicolumn{2}{|c|}{ All Consumers }} & \multirow{2}{*}{\multicolumn{2}{|c|}{$\begin{array}{c}\begin{array}{c}\text { Raw-Material-Sensitive } \\
\text { Premium Brand Customers }\end{array} \\
\text { Group } 1\end{array}$}} & \multicolumn{2}{|c|}{$\begin{array}{c}\text { Raw-Material-Sensitive } \\
\text { Customers (Guano } \\
\text { Avoiding) } \\
\end{array}$} & \multicolumn{2}{|c|}{$\begin{array}{l}\text { Label-Oriented } \\
\text { Middle-Class } \\
\text { Customers }\end{array}$} & \multicolumn{2}{|c|}{$\begin{array}{l}\text { Price-Sensitive } \\
\text { Customers }\end{array}$} & \multicolumn{2}{|c|}{$\begin{array}{c}\text { Multicriteria } \\
\text { Customers (Guano } \\
\text { Seeking) }\end{array}$} \\
\hline & & & & & & & & & & & & & \\
\hline & & \multicolumn{2}{|c|}{$\mathrm{n}=507$} & \multicolumn{2}{|c|}{$n=61$} & \multicolumn{2}{|c|}{$\mathrm{n}=55$} & \multicolumn{2}{|c|}{$\mathrm{n}=115$} & \multicolumn{2}{|c|}{$\mathrm{n}=127$} & \multicolumn{2}{|c|}{$\mathrm{n}=149$} \\
\hline & & Mean & S.D. & Mean & S.D. & Mean & S.D. & Mean & S.D. & Mean & S.D. & Mean & S.D. \\
\hline Potting soil type & Flower potting soil & 0.39 & 0.11 & -0.54 & 0.21 & 0.34 & 0.19 & -4.00 & 0.62 & -0.04 & 0.07 & 2.20 & 0.12 \\
\hline \multirow{2}{*}{ Brand } & Premium brand & 0.10 & 0.04 & 2.42 & 0.36 & -0.40 & 0.21 & -4.00 & 0.68 & -0.30 & 0.09 & 0.74 & 0.11 \\
\hline & Middle class brand & 0.08 & 0.02 & -0.48 & 0.16 & -0.21 & 0.16 & 4.00 & 0.71 & -0.11 & 0.08 & 2.08 & 0.13 \\
\hline Label I & Labeled "organic" & 0.52 & 0.52 & 3.00 & 0.31 & 0.70 & 0.21 & 4.00 & 0.41 & 0.11 & 0.06 & 2.15 & 0.14 \\
\hline Label II & Labeled "peat free" & 0.46 & 0.14 & 3.00 & 0.31 & 0.30 & 0.15 & 4.00 & 0.63 & -0.16 & 0.09 & 2.12 & 0.11 \\
\hline Label III & Labeled "containing guano" & 0.37 & 0.12 & -4.00 & 0.34 & -1.28 & 0.21 & -4.00 & 0.67 & -0.17 & 0.05 & 4.00 & 0.62 \\
\hline \multirow{2}{*}{ Raw material } & From renewable resources & 2.21 & 0.21 & 4.00 & 0.33 & 3.11 & 0.31 & -4.00 & 0.71 & 0.21 & 0.07 & 2.44 & 0.16 \\
\hline & From fermentation residues & 0.74 & 0.12 & 3.83 & 0.29 & 0.93 & 0.21 & -4.00 & 0.68 & 0.08 & 0.04 & 2.13 & 0.13 \\
\hline
\end{tabular}

Red: negative WTP. * The maximum price difference we asked for in the exercise was 4.00 euro. Therefore, we could not estimate WTP values larger than 4 euro. "4.00 euro" should be read as at least 4.00 euro.

Table 4. Average WTP for attributes by strength of proenvironmental attitudes.

\begin{tabular}{|c|c|c|c|c|c|c|c|c|c|}
\hline \multirow[b]{4}{*}{ Attribute } & \multirow[b]{4}{*}{ Level } & \multicolumn{8}{|c|}{ Strength of Proenvironmental Attitudes } \\
\hline & & \multirow{2}{*}{\multicolumn{2}{|c|}{$\begin{array}{c}\text { High } \\
\mathrm{n}=181\end{array}$}} & \multirow{2}{*}{\multicolumn{2}{|c|}{$\begin{array}{c}\text { Medium } \\
\mathrm{n}=192\end{array}$}} & \multirow{2}{*}{\multicolumn{2}{|c|}{$\begin{array}{c}\text { Low } \\
\mathrm{n}=114\end{array}$}} & \multirow{2}{*}{\multicolumn{2}{|c|}{$\begin{array}{c}\text { Very Low } \\
n=20\end{array}$}} \\
\hline & & & & & & & & & \\
\hline & & Mean & S.D. & Mean & S.D. & Mean & S.D. & Mean & S.D. \\
\hline $\begin{array}{l}\text { Potting soil } \\
\text { type }\end{array}$ & Flower potting soil & 2.11 & 0.11 & 0.38 & 0.09 & 0.12 & 0.10 & -0.22 & 0.21 \\
\hline \multirow{2}{*}{ Brand } & Premium brand & 1.73 & 0.09 & 0.11 & 0.08 & -0.35 & 0.11 & -0.33 & 0.24 \\
\hline & Middle class brand & 1.42 & 0.10 & 0.03 & 0.07 & -0.09 & 0.10 & -0.15 & 0.22 \\
\hline Label II & Labeled "peat free" & 2.24 & 0.13 & 0.41 & 0.09 & 0.00 & 0.13 & -0.18 & 0.19 \\
\hline Label III & Labeled "containing guano" & -2.31 & 0.11 & -0.29 & 0.04 & 0.03 & 0.09 & 0.26 & 0.18 \\
\hline \multirow{2}{*}{ Raw material } & From renewable resources & 3.86 & 0.15 & 2.02 & 0.13 & 1.28 & 0.15 & 0.70 & 0.16 \\
\hline & From fermentation residues & 2.48 & 0.13 & 0.54 & 0.09 & 0.48 & 0.11 & -0.10 & 0.21 \\
\hline
\end{tabular}

Red: negative WTP 
The proenvironmental attributes "organic" and "peat free" elicit a near-zero (or negative) WTP from consumers with "very low" or "low" concern for the environment. Those whose attitudes toward environmental protection are of "medium" strength show a positive WTP of about 50 cents, while those of "high" strength show a WTP of more than two euros.

A similar pattern prevails with regard to "from renewable resources" and "from fermentation residues", where again WTP increases with the strength of proenvironmental attitudes. The pattern's inverse is evident in responses to "containing guano", where WTP decreases with stronger proenvironmental attitudes.

The fact that WTP for the raw material options that do not explicitly name biogas increases with stronger proenvironmental attitudes can be interpreted to mean that negative perceptions of biogas technology are more pronounced the stronger the consumer's proenvironmental attitudes are.

\subsection{Willingness to Pay for Products from a Biogas Plant}

Overall, Table 3 shows the attributes "from renewable resources" and "from fermentation residues" elicited a positive WTP from our respondents over the explicit option "from biogas residues". A pattern emerges where an origin in "renewable resources" elicits a higher WTP than an origin in "fermentation residues", which in turn elicits a higher WTP than "biogas residues". Note that all three descriptors apply to the same digestate-based resource.

Overall, "from renewable resources" elicited a premium of 2.21 euros over "from biogas residues" and a premium of 1.47 over "from fermentation residues". Except for group 3 ("label-oriented middle-class customers"), all latent classes showed a positive WTP for "from fermentation residues" over "from biogas residues".

Groups 1 and 2 ("raw-material-sensitive" customers) were willing to pay 4.00 and 3.11 euro, respectively, for the most valued option of "renewable resources". However, group 1 showed a premium of only 17 cents for "renewable resources" over "fermentation residues", while group 2 was willing to pay a premium of more than two euros (2.18) for an origin described as "from renewable resources" over one described as "from fermentation residues".

Group 5 followed the pattern of group 1, only with smaller WTPs: 2.44 and 2.13 for "renewable" and "fermentation", respectively, vs the 4.00 and 3.83 recorded for group 1 .

Customers in group 4 ("price sensitive") showed near-zero WTPs, manifesting their seeming indifference to the raw-material origins of the soil. Those in group 3 ("label-oriented middle class") exhibited a maximum negative WTP for both "from renewable resources" and "from fermentation residues".

Thus, in all latent classes but group 3, Hypothesis 3 is supported.

\subsection{The Influence of Sales Channels}

Table 5 presents the average WTPs associated with each of the potting soil attributes, here grouped by sales channel. The majority of our respondents buy potting-soil products in DIY markets $(68 \%)$ followed by nurseries (17\%) (Figure 3). Generally, the WTP of nursery customers for the proenvironmental attributes "organic", "peat free", and the absence of "with guano" is much higher than that of DIY customers. It is only topped by the WTP of customers buying direct at a composting plant. Customers buying in a supermarket exhibit the lowest WTP for proenvironmental attributes. These results support Hypothesis 4.1. 
Table 5. Average WTP for attributes by store types.

\begin{tabular}{|c|c|c|c|c|c|c|c|c|c|}
\hline \multirow[b]{4}{*}{ Attribute } & \multirow[b]{4}{*}{ Level } & \multicolumn{8}{|c|}{ Store Type } \\
\hline & & \multirow{2}{*}{\multicolumn{2}{|c|}{$\begin{array}{c}\text { CompostingPlant } \\
\mathrm{n}=35\end{array}$}} & \multirow{2}{*}{\multicolumn{2}{|c|}{$\begin{array}{c}\text { Nursery } \\
n=85\end{array}$}} & \multirow{2}{*}{\multicolumn{2}{|c|}{$\begin{array}{c}\text { DIY Store } \\
\mathrm{n}=334\end{array}$}} & \multirow{2}{*}{\multicolumn{2}{|c|}{$\begin{array}{c}\text { Supermarket } \\
n=36\end{array}$}} \\
\hline & & & & & & & & & \\
\hline & & Mean & S.D. & Mean & S.D. & Mean & S.D. & Mean & S.D. \\
\hline Potting soil type & Flower potting soil & 2.45 & 0.17 & 0.62 & 0.11 & 0.40 & 0.10 & -0.04 & 0.11 \\
\hline \multirow{2}{*}{ Brand } & Premium brand & -4.00 & 0.16 & 1.33 & 0.13 & 0.06 & 0.09 & -0.07 & 0.13 \\
\hline & Middle class brand & 2.04 & 0.19 & 0.77 & 0.12 & 0.03 & 0.08 & 0.05 & 0.12 \\
\hline Label I & Labeled as "organic" & 2.46 & 0.18 & 1.41 & 0.13 & 0.43 & 0.09 & 0.10 & 0.10 \\
\hline Label II & Labeled as "peat free" & 2.80 & 0.17 & 1.97 & 0.11 & 0.34 & 0.07 & -0.24 & 0.13 \\
\hline Label III & Labeled as "containing guano" & -4.00 & 0.38 & -4.00 & 0.46 & 0.28 & 0.09 & 0.20 & 0.12 \\
\hline \multirow{2}{*}{ Raw material } & From renewable resources & 3.86 & 0.11 & 3.54 & 0.21 & 2.06 & 0.11 & 0.69 & 0.11 \\
\hline & From fermentation residues & 2.77 & 0.14 & 0.80 & 0.09 & 0.69 & 0.06 & 0.48 & 0.09 \\
\hline
\end{tabular}

Red: negative WTP 


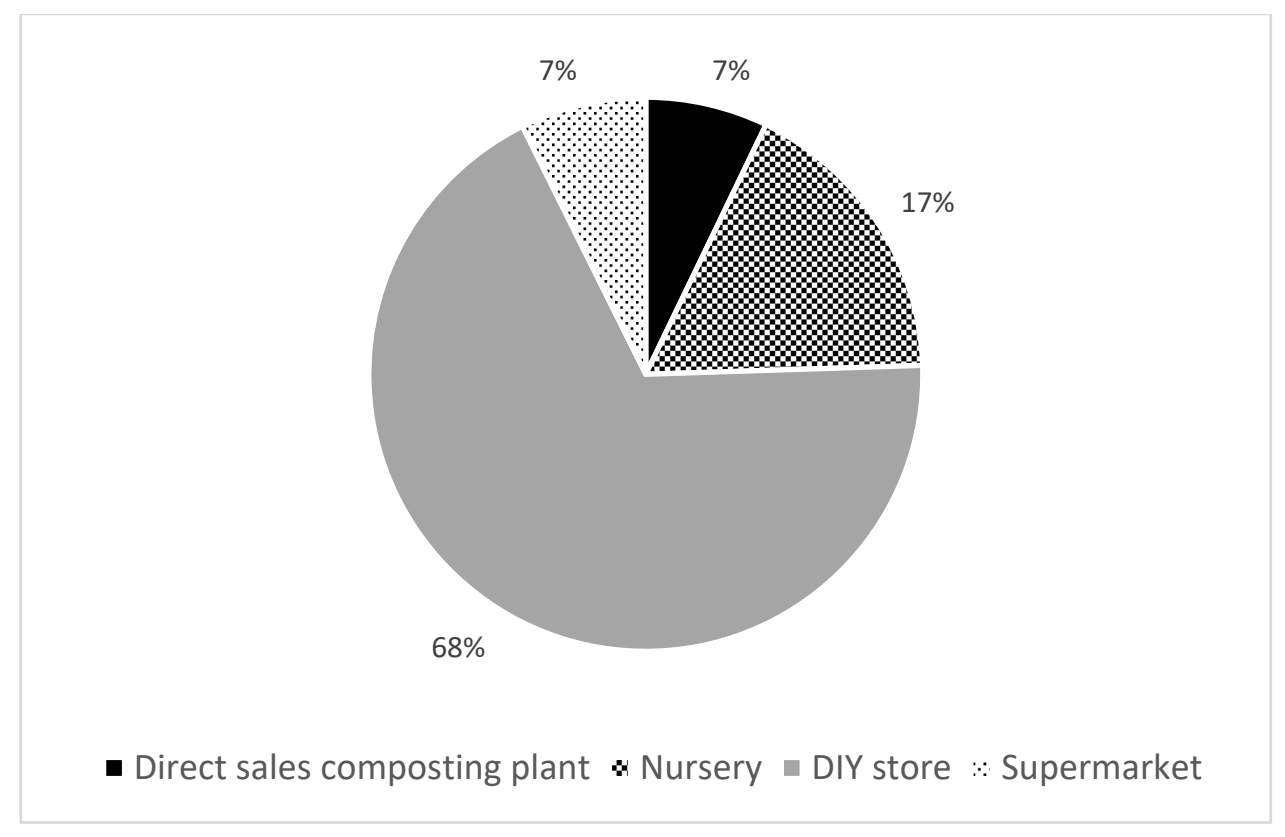

Figure 3. Share of consumers for different store types.

Our results with regard to sales channels, however, have to be treated with caution. Only 14 out of 495 respondents buy potting-soil products online. They overall show a much higher WTP for proenvironmental attributes than those who buy these products in a store. However, due to the small sample size, we cannot make statistically robust statements regarding Hypothesis 4.2.

\section{Discussions and Conclusions}

We conducted a discrete choice experiment (DCE) to estimate consumer willingness to pay (WTP) for proenvironmental attributes in potting-soil products. The DCE generated 6084decisions made by the 507 qualified home gardeners who participated in an online questionnaire. Our results yield insights for companies offering compost or potting soil based on biogas digestate. We discuss these first in terms of market segmentation and then in terms of three key marketing strategies: product, communication, and distribution.

\subsection{Implications for Marketing Digestate-Based Products}

\subsubsection{Segmented Marketing Approaches}

Many companies perform market segmentation and follow a differentiated marketing approach by segment. While the segmentation discovered in the five latent classes of Section 4.1 may challenge marketing practitioners, a segmentation by proenvironmental attitudes represents a psychographic approach common in current practice. For marketers of digestate- or compost-based products, our results make clear that products designed to appeal to consumers with strong proenvironmental attitudes offer the best revenue opportunities. Products that are "organic" and "peat free" elicit from those with strong attitudes a WTP more than two euros higher than the WTP elicited from those whose concerns for the environment are low or very low.

At the same time, marketers of digestate-based potting soil face a positioning challenge. Our results demonstrate that those with the strongest proenvironmental attitudes also harbor the most pronounced reservations about biogas. In describing the origin of the potting soil, the words "renewable" and "resources"- two words with positive connotations—garnered the highest WTP. Describing the source as "residues" lowered WTP, and adding "biogas" to "residues" produced the lowest. The connotation of "biogas" depends on the country, being strongly negative in Germany but positive in Finland. These considerations are relevant to effective product and communication strategies. 


\subsubsection{Product Strategy}

When designing a product, a provider must decide between an application-neutral and an application-specific product design. Our results identified two latent classes: group 1 ("raw-material-sensitive premium customers") and group 3 ("label-oriented middle-class customers"), from whom were elicited the highest WTPs for the combination "organic", "peat free", and "not from guano". These three attributes represent the "proenvironmental" set and, for both groups 1 and 3, an application-specific soil, i.e., one designed for flowering vs general-purpose use, elicited negative WTPs. This suggests the most effective strategy to appeal to these consumers is to combine the proenvironmental attributes of a digestate-based product with an application-neutral design.

\subsubsection{Communication Strategies}

In product communication, it is an effective approach to combine the three proenvironmental attributes of digestate-based products, namely, being "organic", "peat free", and without guano, since 297 out of 507 (59\%) respondents show significant positive WTP for all three. Only the "multicriteria customers" (29\%) exhibit positive WTP for the former two proenvironmental attributes while still preferring guano.

\subsubsection{Distribution Strategies}

Our results on WTP for the four different sales channels in our DCE (composting plant, nursery, DIY store, and supermarket) speak in favor of direct sales by the biogas plant rather than going through a retailer, as consumers exhibit the highest WTP for proenvironmental attitudes for products purchased directly at a composting plant. However, selling directly on the premises of a biogas plant means that the biogas origin is clearly visible to the customer, which our results indicate is detrimental. However, a customer going to a composting plant is not naïve about the product's origins, which might be inferred from the relatively small difference in WTP between an origin in "renewable resources" and one in "fermentation residues" for this group (1.09 euro) compared to the nursery sales channel (2.74 euro). Still, we consider that direct sales can only be a niche strategy, perhaps a profitable one, but not an effective distribution strategy for the entire digestate stream of a plant.

Larger scale distribution of biogas digestate-based products can be facilitated through strategies that include partnerships with other market actors, an approach whose success likely depends on targeting the right sales channels. Taken as a whole, our respondents showed an almost negligible WTP for premium or middle-class brands over a private label. However, group 1, comprising slightly more than $12 \%$ of the respondent pool, seems to offer an opportunity for a marketer since it is willing to pay nearly the max for the triad of proenvironmental attributes. This group is also willing to pay the max for an origin in renewable resources and almost as much (3.83) for an origin in fermented residues. What is key to reaching the group, however, is associating a digestate or compost product with a premium brand, as that is the WTP preference of this group.

Only two other groups-group 3 ("label-oriented middle-class customers"), representing slightly more than $22 \%$ of the respondents, and group 5 ("guano seeking"), representing almost $30 \%$ of the respondents-show a positive WTP based on brand. Both show a preference for a "middle-class brand" over a premium brand. For group 3, the preference is as strong as possible: a positive 4.00 euro for the middle-class brand, and a negative 4.00 euro for the premium brand. For group 5 , the preference is still present but less dramatic: 2.08 euro for the middle-class brand compared to 0.74 for the premium.

Overall, it is fair to say that the proenvironmental attributes of digestate- and compost-based potting soils generate opportunities for obtaining price premia. However, appealing to the consumer requires a nuanced approach. Education plays a key role, as the fact that our respondents showed strongly differentiated WTP for three descriptors of the same digestate-based product indicates that attitudes, not facts, often drive decisions. To our respondents, the term "biogas" was predominantly pejorative. However, opportunities to meet demand for organic and peat-free products clearly exist. 
Nonetheless, the marketing of digestate-based products remains a demanding task for the biogas sector, as it must now engage the environmentally conscious consumer to open up alternatives to the established use of digestate in the agricultural sector.

\subsection{Contextualization with Previous Studies and Avenues for Future Research}

Overall, our results are in line with previous research that found an increased WTP for proenvironmental products and services (see Section 2.6). Also, the importance of digestate-specific proenvironmental levels of attributes [25] is mirrored in the WTP results. The importance of the attribute "organic" and differences between consumer segments has also been shown in a study on how U.S. consumers make their choices on home lawn fertilizers [82]. However, the mixed results for guano show that, for some attributes, it might be less than clear which level is best from an environmental point of view. The positive effect of proenvironmental values on WTP in general we found for the digestate-based potting-soil products is also in line with prior research. The strong penalization of the biogas origin in WTP puts a number on the hitherto only qualitative findings on the population's concerns with biogas [77].

Future research could expand the scope of analysis beyond product attributes. Our study, like the majority of WTP studies on proenvironmental products and services, is restricted to what [83] call "utilitarian benefits", i.e., attributes that relate to the products' proenvironmental effects. However, these products also may generate a "warm glow" feeling with consumers, i.e., a positive emotional effect based on a person's morally superior behavior. They may also offer consumers the opportunity to reap or satisfy self-expressive motives, i.e., to demonstrate proenvironmental consumption to others and thus to increase their social status [83].

Author Contributions: Conceptualization, C.H., J.D., and P.K.; methodology, P.K.; investigation, J.D. and P.K.; data curation, P.K.; writing-original draft preparation, C.H., J.D., and P.K.; writing-review and editing, C.H; project administration, C.H.; funding acquisition, C.H. All authors have read and agreed to the published version of the manuscript.

Funding: This research was funded within the framework of the research project GAERWERT (grant no. 22402312). The project was supported by Fachagentur Nachwachsende Rohstoffe e.V. (FNR) on behalf of the German Federal Ministry of Food and Agriculture. The article processing charge was funded by the Baden-Württemberg Ministry of Science, Research and Culture and the Nuertingen-Geislingen University in the funding program Open Access Publishing.

Acknowledgments: We would like to thank Charles Duquette for his editing support.

Conflicts of Interest: The authors declare no conflict of interest.

\section{References}

1. Scarlat, N.; Dallemand, J.-F.; Fahl, F. Biogas: Developments and perspectives in Europe. Renew. Energy 2018, 129, 457-472. [CrossRef]

2. European Biogas Association. Statistical Report 2017. Abridged Version; EBA: Brussels, Belgium, 2017; Available online: https://european-biogas.eu/wp-content/uploads/2017/12/Statistical-report-of-the-European-BiogasAssociation_excerpt-web.pdf (accessed on 5 May 2020).

3. International Renewable Energy Agency. Renewable Capacity Statistics 2018; IRENA: Abu Dhabi, UAE, 2018; Available online: https://www.irena.org/-/media/Files/IRENA/Agency/Publication/2018/Mar/IRENA_RE_ Capacity_Statistics_2018.pdf (accessed on 4 May 2020).

4. Koszel, M.; Lorencowicz, E. Agricultural Use of Biogas Digestate as a Replacement Fertilizers. Agricult. Agricult. Sci. Proc. 2015, 7, 119-124. [CrossRef]

5. Yu, F.-B.; Luo, X.-P.; Song, C.-F.; Zhang, M.-X.; Shan, S.-D. Concentrated biogas slurry enhanced soil fertility and tomato quality. Acta Agricult. Scand. Sect. B Soil Plant Sci. 2010, 60, 262-268. [CrossRef]

6. Bolzonella, D.; Fatone, F.; Gottardo, M.; Frison, N. Nutrients recovery from anaerobic digestate of agro-waste: Techno-economic assessment of full scale applications. J. Environ. Manag. 2018, 216, 111-119. [CrossRef] [PubMed] 
7. Petravić-Tominac, V.; Nastav, N.; Buljubašić, M.; Šantek, B. Current state of biogas production in Croatia. Energy Sustain. Soc. 2020, 10, 8. [CrossRef]

8. Möller, K.; Müller, T. Effects of anaerobic digestion on digestate nutrient availability and crop growth: A review. Eng. Life Sci. 2012, 12, 242-257. [CrossRef]

9. Möller, K. Charakterisierung und Eignung von organischen Charakterisierung und Eignung von organischen Handelsdüngemitteln für den Einsatz im ökologischen Landbau. In Ideal und Wirklichkeit_Perspektiven Ökologischer Landbewirtschaftung: Beiträge zur 12. Wissenschaftstagung Ökologischer Landbau, Bonn, 5-8 März 2013; Neuhoff, D., Stumm, C., Ziegler, S., Rahmann, G., Hamm, U., Koepke, U., Eds.; Verlag Dr. Köster: Berlin, Germany, 2013; pp. 224-227.

10. Herbes, C.; Roth, U.; Wulf, S.; Dahlin, J. Economic assessment of different biogas digestate processing technologies: A scenario-based analysis. J. Clean. Prod. 2020, 255, 120282. [CrossRef]

11. Sogn, T.A.; Dragicevic, I.; Linjordet, R.; Krogstad, T.; Eijsink, V.G.H.; Eich-Greatorex, S. Recycling of biogas digestates in plant production: NPK fertilizer value and risk of leaching. Int. J. Recycl. Org. Waste Agricul. 2018, 7, 49-58. [CrossRef]

12. Dahlin, J.; Herbes, C.; Nelles, M. Biogas digestate marketing: Qualitative insights into the supply side. Resour. Conserv. Recycl. 2015, 104, 152-161. [CrossRef]

13. Wendland, M. Neue Düngeverordnung in Bayern-Einfluss auf Landwirtschaft und Wasserwirtschaft. In Von Milchseeen zur Butterknappheit. Was Kommt als Nächstes? HBLFA Raumberg-Gumpenstein: Irdning-Donnersbachtal, Austria, 2018; pp. 35-37. ISBN 978-3-902849-55-7.

14. Uhlenhaut, T. Gülleflut in Niedersachsen Stoppen! Verbände Fordern Masterplan für Sauberes Grundwasser, Flüsse und die Nordsee. Available online: https://www.greenpeace.de/sites/www.greenpeace.de/files/ publications/180328-pm-naehrstoffbericht_gp-nabu-bund.pdf (accessed on 3 February 2020).

15. Kiefer, J.; Ball, T. Beurteilung der Erzeugung von Biomasse zur energetischen Nutzung aus Sicht des Gewässerschutzes. Energie Wasser Praxis 2008, 6, 36-43.

16. Turetsky, M.R.; Benscoter, B.; Page, S.; Rein, G.; van der Werf, G.R.; Watts, A. Global vulnerability of peatlands to fire and carbon loss. Nat. Geosc. 2014, 8, 11. [CrossRef]

17. Waddington, J.M.; Price, J.S. Effect of peatland drainage, harvesting, and restoration on atmospheric water and carbon exchange. Phys. Geogr. 2000, 21, 433-451. [CrossRef]

18. PR Newswire. Peat Market—Europe Industry Analysis, Size, Share, Growth, Trends, and Forecast 2016-2024; Y, 2017. PR Newswire US. Available online: http://www.redi-bw.de/db/ebsco.php/search.ebscohost.com/ login.aspx\%3fdirect\%3dtrue\%26db\%3dbwh\%26AN\%3d201707051940PR.NEWS.USPR.BR32709\%26lang\% 3dde\%26site\%3dehost-live (accessed on 7 March 2020).

19. Tampio, E.; Marttinen, S.; Rintala, J. Liquid fertilizer products from anaerobic digestion of food waste: Mass, nutrient and energy balance of four digestate liquid treatment systems. J. Clean. Prod. 2016, 125, 22-32. [CrossRef]

20. Rehl, T.; Müller, J. Life cycle assessment of biogas digestate processing technologies. Resour. Conserv. Recycl. 2011, 56, 92-104. [CrossRef]

21. Fuchs, W.; Drosg, B. Assessment of the state of the art of technologies for the processing of digestate residue from anaerobic digesters. WST 2013, 67, 1984-1993. [CrossRef]

22. Dahlin, J.; Beuthner, C.; Halbherr, V.; Kurz, P.; Nelles, M.; Herbes, C. Sustainable compost and potting soil marketing: Private gardener preferences. J. Clean. Prod. 2019, 208, 1603-1612. [CrossRef]

23. Tur-Cardona, J.; Bonnichsen, O.; Speelman, S.; Verspecht, A.; Carpentier, L.; Debruyne, L.; Marchand, F.; Jacobsen, B.H.; Buysse, J. Farmers' reasons to accept bio-based fertilizers: A choice experiment in seven different European countries. J. Clean. Prod. 2018, 197, 406-416. [CrossRef]

24. Pappalardo, G.; Selvaggi, R.; Lusk, J.L. Procedural Invariance as a Result of Commitment Costs: Evidence from an Economic Experiment on Farmers' Willingness to Pay for Digestate. Appl. Econ. Lett. 2019, 26, 1243-1246. [CrossRef]

25. Dahlin, J.; Nelles, M.; Herbes, C. Biogas digestate management: Evaluating the attitudes and perceptions of German gardeners towards digestate-based soil amendments. Resour. Conserv. Recycl. 2017, 118, 27-38. [CrossRef]

26. Louviere, J.J.; Woodworth, G. Design and Analysis of Simulated Consumer Choice or Allocation Experiments: An Approach Based on Aggregate Data. J. Mark. Res. 1983, 20, 350-367. [CrossRef] 
27. Lenk, P.J.; Desarbo, W.S.; Green, P.E.; Young, M.R. Hierarchical Bayes Conjoint Analysis: Recovery of Partworth Heterogeneity from Reduced Experimental Designs. Mark. Sci. 1996, 15, 173-191. [CrossRef]

28. Allenby, G.M.; Ginter, J.L. Using Extremes to Design Products and Segment Markets. J. Mark. Res. 1995, 32, 392-403. [CrossRef]

29. Allenby, G.M.; Arora, N.; Ginter, J.L. Incorporating Prior Knowledge into the Analysis of Conjoint Studies. J. Mark. Res. 1995, 32, 152-162. [CrossRef]

30. Williamson, P.O.; Lockshin, L.; Francis, I.L.; Mueller Loose, S. Influencing consumer choice: Short and medium term effect of country of origin information on wine choice. Food Qual. Prefer. 2016, 51, 89-99. [CrossRef]

31. Meyerding, S.G.H. Consumer preferences for food labels on tomatoes in Germany-A comparison of a quasi-experiment and two stated preference approaches. Appetite 2016, 103, 105-112. [CrossRef]

32. Balcombe, K.; Bradley, D.; Fraser, I.; Hussein, M. Consumer Preferences Regarding Country of Origin for Multiple Meat Products. Food Policy 2016, 64, 49-62. [CrossRef]

33. Tuhkanen, H.; Piirsalu, E.; Nõmmann, T.; Karlõševa, A.; Nõmmann, S.; Czajkowski, M.; Hanley, N. Valuing the benefits of improved marine environmental quality under multiple stressors. Sci. Total Environ. 2016, 551-552, 367-375. [CrossRef]

34. Rakotonarivo, O.S.; Schaafsma, M.; Hockley, N. A systematic review of the reliability and validity of discrete choice experiments in valuing non-market environmental goods. J. Environ. Manag. 2016, 183, 98-109. [CrossRef]

35. Rakotonarivo, O.S.; Jacobsen, J.B.; Larsen, H.O.; Jones, J.P.G.; Nielsen, M.R.; Ramamonjisoa, B.S.; Mandimbiniaina, R.H.; Hockley, N. Qualitative and Quantitative Evidence on the True Local Welfare Costs of Forest Conservation in Madagascar: Are Discrete Choice Experiments a Valid ex ante Tool? World Dev. 2017, 94, 478-491. [CrossRef]

36. Narjes, M.E.; Lippert, C. Longan fruit farmers' demand for policies aimed at conserving native pollinating bees in Northern Thailand. Ecosyst. Serv. 2016, 18, 58-67. [CrossRef]

37. Lancaster, K.J. A New Approach to Consumer Theory. J. Political Econ. 1966, 74, 132-157. [CrossRef]

38. Rao, V.R. Applied Conjoint Analysis; Springer: Heidelberg, Germany, 2014.

39. McFadden, D.; Train, K. Mixed MNL models for discrete response. J. Appl. Econ. 2000, 15, 447-470. [CrossRef]

40. McFadden, D. The Choice Theory Approach to Market Research. Mark. Sci. 1986, 5, 275-297. [CrossRef]

41. McFadden, D. Conditional logit analysis of qualitative choice behavior. In Frontiers in Econometrics; Academic Press: New York, NY, USA, 1974; pp. 105-142.

42. Train, K. Discrete Choice Methods with Simulation.; Cambridge University Press: Cambridge, UK, 2009.

43. Louviere, J.J.; Flynn, T.N.; Carson, R.T. Discrete Choice Experiments Are Not Conjoint Analysis. J. Choice Model. 2010, 3, 57-72. [CrossRef]

44. Levy, M.; Grewal, D.; Kopalle, P.K.; Hess, J.D. Emerging trends in retail pricing practice: Implications for research. J. Retail. 2004, 80, xiii. [CrossRef]

45. Wang, T.; Venkatesh, R.; Chatterjee, R. Reservation Price as a Range: An Incentive-Compatible Measurement Approach. J. Mark. Res. 2007, 44, 200-213. [CrossRef]

46. Breidert, C.; Hahsler, M.; Reutterer, T. A Review of Methods for Measuring Willingness-to-Pay. Innovat. Mark. 2006, 2, 8-32.

47. Wittink, D.R.; Vriens, M.; Burhenne, W. Commercial use of conjoint analysis in Europe: Results and critical reflections. Int. J. Res. Mark. 1994, 11, 41-52. [CrossRef]

48. Wittink, D.R.; Cattin, P. Commercial Use of Conjoint Analysis: An Update. J. Mark. 1989, 53, 91-96. [CrossRef]

49. Sapede, C.; Girod, I. Willingness of Adults in Europe to Pay for a New Vaccine: The Application of Discrete Choice-Based Conjoint Analysis. Int. J. Market Res. 2002, 44, 1-13. [CrossRef]

50. Gilbride, T.J.; Lenk, P.J.; Brazell, J.D. Market Share Constraints and the Loss Function in Choice-Based Conjoint Analysis. Mark. Sci. 2008, 27, 995-1011. [CrossRef]

51. Brazell, J.D.; Diener, C.G.; Karniouchina, E.; Moore, W.L.; Séverin, V.; Uldry, P.-F. The no-choice option and dual response choice designs. Mark. Lett. 2006, 17, 255-268. [CrossRef]

52. Natter, M.; Feurstein, M. Correcting for CBC model bias: A hybrid scanner data-conjoint model. Int. Rev. Retail Distrib. Consum. Res. 2001, 11, 247-254. [CrossRef]

53. Kløjgaard, M.E.; Bech, M.; Søgaard, R. Designing a stated choice experiment: The value of a qualitative process. J. Choice Model. 2012, 5, 1-18. [CrossRef] 
54. Rossi, P.E.; Allenby, G.M. Bayesian Statistics and Marketing. Mark. Sci. 2003, 22, 304-328. [CrossRef]

55. Orme, B. CBC/HB v5: Software for Hierarchical Bayes Estimation for CBC Data; Sawtooth: Ketchum, ID, USA, 2009.

56. Haws, K.L.; Winterich, K.P.; Naylor, R.W. Seeing the world through GREEN-tinted glasses: Green consumption values and responses to environmentally friendly products. J. Consum. Psychol. 2014, 24, 336-354. [CrossRef]

57. Aschemann-Witzel, J.; Zielke, S. Can't Buy Me Green? A Review of Consumer Perceptions of and Behavior toward the Price of Organic Food: Reviews and Commentary. J. Consum. Aff. 2017, 51, 211-251. [CrossRef]

58. Smith, B.; Olaru, D.; Jabeen, F.; Greaves, S. Electric vehicles adoption: Environmental enthusiast bias in discrete choice models. Transp. Res. Part D 2017, 51, 290-303. [CrossRef]

59. Neill, C.L.; Williams, R.B. Consumer Preference for Alternative Milk Packaging: The Case of an Inferred Environmental Attribute. J. Agricult. Appl. Econ. 2016, 48, 241-256. [CrossRef]

60. Hustvedt, G.; Bernard, J.C. Consumer willingness to pay for sustainable apparel: The influence of labelling for fibre origin and production methods. Int. J. Consum. Stud. 2008, 32, 491-498. [CrossRef]

61. Herbes, C.; Friege, C.; Baldo, D.; Mueller, K.-M. Willingness to pay lip service? Applying a neuroscience-based method to WTP for green electricity. Energy Policy 2015, 87, 562-572. [CrossRef]

62. Hensher, D.A.; Rose, J.M.; Greene, W.H. Applied Choice Analysis; Cambridge University Press: Cambridge, UK, 2015.

63. Allenby, G.M.; Brazell, J.; Howell, J.R.; Rossi, P.E. Valuation of Patented Product Features. J. Law Econ. 2014, 57, 629-663. [CrossRef]

64. Dahlin, J.; Halbherr, V.; Kurz, P.; Nelles, M.; Herbes, C. Marketing Green Fertilizers: Insights into Consumer Preferences. Sustainability 2016, 8, 1169. [CrossRef]

65. Byg, A.; Martin-Ortega, J.; Glenk, K.; Novo, P. Conservation in the face of ambivalent public perceptions-The case of peatlands as 'the good, the bad and the ugly'. Biol. Conserv. 2017, 206, 181-189. [CrossRef]

66. Lee, Y.; Kim, S.; Kim, M.; Choi, J. Antecedents and interrelationships of three types of pro-environmental behavior. J. Bus. Res. 2014, 67, 2097-2105. [CrossRef]

67. Scherer, C.; Emberger-Klein, A.; Menrad, K. Segmentation of interested and less interested consumers in sports equipment made of bio-based plastic. Sustain. Prod. Consum. 2018, 14, 53-65. [CrossRef]

68. Pickett-Baker, J.; Ozaki, R. Pro-environmental products: Marketing influence on consumer purchase decision. J. Consum. Mark. 2008, 25, 281-293. [CrossRef]

69. Grønhøj, A.; Thøgersen, J. Action speaks louder than words: The effect of personal attitudes and family norms on adolescents' pro-environmental behaviour. J. Econ. Psychol. 2012, 33, 292-302. [CrossRef]

70. Emberger-Klein, A.; Menrad, K.; Heider, D. Determinants of Consumers' Willingness-to-pay for Fairly-produced, Locally Grown Dairy Products. Ger. J. Agricult. Econ. 2016, 65, 94-111.

71. Barber, N.A.; Taylor, D.C.; Venkatachalam, V. Does the Product Really Matter? A Look at Mainstream Pro-Environmental Consumption Behavior. J. Food Products Mark. 2016, 22, 521-554. [CrossRef]

72. Park, J.; Ha, S. Understanding pro-environmental behaviorA comparison of sustainable consumers and apathetic consumers. Int. J. Retail Distrib. Manag. 2012, 40, 388-403. [CrossRef]

73. Johe, M.H.; Bhullar, N. To Buy or Not to Buy: The Roles of Self-Identity, Attitudes, Perceived Behavioral Control and Norms in Organic Consumerism. Ecol. Econ. 2016, 128, 99-105. [CrossRef]

74. Ertz, M.; Karakas, F.; Sarigöllü, E. Exploring pro-environmental behaviors of consumers: An analysis of contextual factors, attitude, and behaviors. J. Bus. Res. 2016, 69, 3971-3980. [CrossRef]

75. Schumacher, K.; Krones, F.; McKenna, R.; Schultmann, F. Public acceptance of renewable energies and energy autonomy: A comparative study in the French, German and Swiss Upper Rhine region. Energy Policy 2019, 126, 315-332. [CrossRef]

76. Pehlken, A.; Madena, K.; Aden, C.; Klenke, T. Forming stakeholder alliances to unlock alternative and unused biomass potentials in bioenergy regions. J. Clean. Prod. 2016, 110, 66-77. [CrossRef]

77. Herbes, C.; Jirka, E.; Braun, J.P.; Pukall, K. Der gesellschaftliche Diskurs um den "Maisdeckel" vor und nach der Novelle des Erneuerbare-Energien-Gesetzes (EEG) 2012; The Social Discourse on the "Maize Cap\&" before and after the 2012 Amendment of the German Renewable Energies Act (EEG). GAIA 2014, 23, $100-108$. [CrossRef]

78. Herbes, C.; Beuthner, C.; Ramme, I. Consumer attitudes towards biobased packaging-A cross-cultural comparative study. J. Clean. Prod. 2018, 194, 203-218. [CrossRef] 
79. Lyytimäki, J.; Nygrén, N.A.; Pulkka, A.; Rantala, S. Energy transition looming behind the headlines? Newspaper coverage of biogas production in Finland. Energy Sustain. Soc. 2018, 8, 1. [CrossRef]

80. Zhuang, H.; Popkowski Leszczyc, P.T.L.; Lin, Y. Why is Price Dispersion Higher Online than Offline? The Impact of Retailer Type and Shopping Risk on Price Dispersion. J. Retail. 2018, 94, 136-153. [CrossRef]

81. Cuellar, S.S.; Brunamonti, M. Retail channel price discrimination. J. Retail. Consum. Serv. 2014, 21, 339-346. [CrossRef]

82. Campbell, J.; Rihn, A.; Khachatryan, H. Factors Influencing Home Lawn Fertilizer Choice in the United States. HortTechnology 2020, 1-10. [CrossRef]

83. Hartmann, P.; Apaolaza-Ibáñez, V. Consumer attitude and purchase intention toward green energy brands: The roles of psychological benefits and environmental concern. J. Bus. Res. 2012, 65, 1254-1263. [CrossRef]

(C) 2020 by the authors. Licensee MDPI, Basel, Switzerland. This article is an open access article distributed under the terms and conditions of the Creative Commons Attribution (CC BY) license (http://creativecommons.org/licenses/by/4.0/). 